Jurnal Gizi dan Dietetik Indonesia (Indonesian Journal of Nutrition and Dietetics) Vol. 8, No. 1, 2020: 1-8

\section{Stunting among children Indonesian urban areas: What is the risk factors?}

\author{
Tri Siswati ${ }^{1}$, Trynke Hookstra, ${ }^{2}$ Hari Kusnanto ${ }^{3}$
}

${ }^{1}$ Poltekkes Kemenkes Yogyakarta, Tata Bumi no 3 Banyuraden, Gamping, Sleman Regency, Special Region of Yogyakarta, Indonesia, 55293

${ }^{2}$ Vrije Universiteit, De Boelelaan 1105, 1081 HV Amsterdam, Netherland

${ }^{3}$ Faculty of Medicine, Public Health and Nursing, Universitas Gadjah Mada, North Sekip, Sinduadi, Mlati, Sleman Regency, Special Region of Yogyakarta, Indonesia. 55281

${ }^{*}$ Coressponding author. trisiswati14@gmail.com

\begin{abstract}
ABSTRAK
Latar Belakang: Stunting adalah malnutrisi kronis yang dapat terjadi pada semua balita termasuk balita di daerah perkotaan.

Tujuan: Penelitian ini bertujuan untuk mengetahui faktor risiko stunting pada anak-anak 0-59 bulan di perkotaan di Indonesia.

Metode: Penelitian ini merupakan penelitian cross sectional dengan menggunakan data sekunder berdasarkan Riskesdas tahun 2013. Sampel berjumlah 13.248 anak usia 0-59 bulan dari 33 provinsi, yang tinggal di daerah perkotaan, lahir tunggal (37 minggu), usia $\geq 37$ minggu kehamilan, skor TB/U -5, 99 hingga TB/U 5,99 SD, dan data yang diobservasi lengkap. Variabel bebas adalah karakteristik anak (usia, jenis kelamin, berat dan panjang lahir); dan karakteristik rumah tangga (usia orang tua, tinggi badan orang tua, pendidikan, pekerjaan, tingkat ekonomi), sedangkan variabel terikat adalah stunting. Analisis dilakukan dengan regresi logistik multivariat menggunakan Stata13.

Hasil: Faktor yang berhubungan dengan terjadinya stunting balita di perkotaan adalah BBLR (AOR 1,2 CI 95\% 1,09-1,32); dan bayi lahir pendek (AOR 1, 16 CI95\%: 1,99-1,23) dan karakteristik rumah tangga seperti ayah pendek (AOR 1,24, Cl95\% 1,18-1,31); ibu pendek (AOR 1,23, Cl95\% 1,17-1,29); ibu berpendidikan rendah (AOR 1,14, CI 95\% 1,02-1,23); ayah berpendidikan rendah (AOR 1,13, Cl95\% 1,02-1,23), dan tingkat ekonomi menengah dan rendah (AOR 1,12, CI 95\% 1,06-1,19; AOR 1,24, Cl95\% 1,15-1,33).
\end{abstract}

Kesimpulan: Faktor yang berhubungan dengan stunting balita di perkotaan adalah BBLR dan tinggi badan orang tua.

KATA KUNCI: balita; determinan; Indonesia; perkotaan; stunting

Background:Childhood stunting is a form of chronic malnutrition, including among children in the urban area. Objectives: This research was to determine the risk factors of 0-59 months stunting children in urban Indonesia. Methods: This was a cross sectional study using secondary data based Indonesia's Basic Health Research 2013. Samples were a total of 13,248 children aged 0-59 months from 33 provinces, urban residency, singleton, $\geq 37$ weeks gestation, and HAZ score -5.99 to $5.99 \mathrm{SD}$. Independent variables were children characteristics (age, sex, size of birth); and household characteristics (parental age, high, education, employment, economic level), while the dependent variable was stunting. Multivariate logistic regression analysis was performed using Stata 13.

Results: Children characteristics such as low birth weight (AOR $1.2 \mathrm{Cl}$ 95\% 1.09-1.32); and short newborn length (AOR $1.16 \mathrm{Cl} 95 \%: 1.99-1.23)$ and stature father (AOR 1.24, Cl95\% 1.18-1.31) and mother (AOR 1.23, Cl95\% 1.17-1.29); maternal low education (AOR 1.14, CI 95\% 1.02-1.23); paternal low education(AOR 1.13, Cl95\% 1.02-1.23), low middle economic level (AOR 1.12, CI 95\% 1.06-1.19; AOR 1.24, CI95\% 1.15-1.33) were factors associated with urban stunting children.

Conclusion: Low birth weight and short stature were dominant factors associated with stunting children in Indonesian urban areas.

KEYWORDS: children; determinant; Indonesian; urban; stunting 


\section{INTRODUCTION}

Stunting is the most prevalent chronic malnutrition form in Indonesia and other developing countries (1). One fifth children are stunted (1), and it tend to be stunted in a whole life cycles (2). Stunting is not only a problem of short stature but may also be at risk of it's short and long term consequences (1)

Short term consequences of stunting included the risk of illness, irreversible body damage, cognitive impairement, decreased cognitive function, developmental disorders, mortality, and metabolism disorder (1, 3-4). While its long term consequences such as low language and motor skills, low learning outcomes and school performance (4), also low adult productivity (5). Stunting in early life cause a lower rate of metabolism, oxidative fat (5) and tend to suffer from metabolic syndrome due to more body fat composition (6). It is relatively to be more overweight and obesity in adolescence and later life (5-6). Hence, obesity increases the risk of metabolic syndrome and chronic degenerative diseases, such as high blood pressure, diabetes mellitus, coronary heart disease, hypercholesterolemia, stroke, and cancer (5-8).

Indonesia's government have been concerned to overcome stunting children in which the prevalence was among the largest countries with stunted problem after Pakistan (45\%), Congo $(43 \%)$, India (39\%), Ethiopia (38\%) (9), and then Indonesia (37.2\%) (10). World Health Organization (WHO) states to focus combat children malnutrition by reducing $40 \%$ of stunted children in 2025 (9). In fact the prevalence of stunting increase as many as $0.4 \%$ per year in Indonesia, from $35.6 \%$ in 2010 (15) to $37.2 \%$ (11) in 2013.

Determinants of stunting are including proximate and distal factors, also direct and indirect factors (12). Hence, in the last two decades, social factors are the most important factor to affect the people's health status (13). The inequality of social and structural factors are an important factor in disparities health status. That factors including economic both macro and micro level, social level, gender, race, education level, occupation, environment, water and sanitation, housing, and policy (13-15). The differences in social level affect the difference in health exposure and disease severity (14).
Studies in developing countries suggested that the nutritional status of children in urban areas is better than children living in rural areas (16-17). The underlying factor was because the residence had a close association with the access to communication, transportation, food, school and health services. Subramanian et al., 2003 and Kien's et al., 2016 stated that children living in an urban area were a protective factor for stunting than rural areas (OR 0.75 and 0.145 respectively) (18). Unfortunately, as many as one-fourth of Indonesian stunted children living in urban areas (11). The objective of the study was to analyze the determinant factors for stunting children in urban areas in Indonesia.

\section{MATERIALS AND METHODS}

This study was a cross-sectional study, using secondary data based on the Indonesian Base Health Research (Riskesdas) 2013. The sample was selected in 2 stages, the first stage includes the list of primary sampling units (PSUs) in the master table. The number of PSUs in the master table was 30,000 selected by probability proportional to size (PPS) with the number of households census population in 2010. The second sample frame were all census buildings in which there were ordinary households (excluding institutional household: dormitory, prison and others). The population were as many as 37,025 children 0-59 aged months. Samples were selection by criterias i.e. living in urban areas, singleton, $\geq 37$ weeks gestation, HAZ score between -5.99 to 5.99 SD, complete data in observed variables. As many as 13,248 under-five children were included in this study.

The independent variables were children characteristics including age (mo's), sex (female and male), birth weight (grams), newborn length (short if $<48 \mathrm{~cm}$ and normal if $\geq 48 \mathrm{~cm}$ ), and family characteristics, i.e parental education (low if <junior high school, middle if senior high school, and high if higher than senior high school), parent's employment status (employed and unemployed), parent's high, (short father if $\leq 160$ $\mathrm{cm}$, short mother if $\leq 150 \mathrm{~cm}$, the number of family members ( $\leq 4$ and $>4$ ), the number of under-five children ( $\leq 2$ and $>2$ ), while the dependent variable 
was stunting children. Stunting children was less than -2 deviation standart height for age $z$ score WHO, while normal stature was 2 deviation standard and up. Economic status were divided into three categories, low (quintil 4 and 5), middle (quintil 3) and high level (quintil $1 \mathrm{nd} 2$ ), measured by on ownership of household goods.

Children characteristics and demographics were collected using individual and household questionnaires, while nutritional status data were collected with a Fesco digital weight scale with 0.1 $\mathrm{kg}$ precision and height measuring by microtoise. Data collection was conducted by a team of trained enumerators with a minimum educational background of health diploma degree, each team consisting of 6 persons including the chairman. This data was guaranteed the validity process and the result of its observation.

Data were analysed by STATA 13. Determinants of stunting children were analysis by logistic regression. The model of determinants of stunting was analysed by multivariate logistic regression by odds ratio $95 \%$ confidence interval (Cl). Variables with probability values less than 0.25 in this bivariable test are subsequently included in the modelling analysis with multivariate analysis. The multivariate test was done by the enter method, while the best fit model as chosen based on aike's information criterion (AIC). The data presenting by text, map, table and graph. The research was approved by MHREC Faculty medicine of UGM No KE/FK/009/EC/2017 dated January 27, 2017.

\section{RESULTS}

A total of 13,248 children aged $0-59$ months included in the study. The prevalence of stunting 0-59 children in Indonesian urban area is $32.16 \%$, minimum 20.34\% (Maluku) and maximum $42.75 \%$ (NTT) (Fig 1). Mostly, $53.74 \%$ of children were $24-59$ aged months, $51.15 \%$ were boys and $95,15 \%$ were normal birth weight. About $41.93 \%$ of mother and $45.52 \%$ of fathers had middle education, $53.40 \%$ had $>4$ number family members, $98.35 \%$ had $\leq 2$ number of children underfives, $69.26 \%$ had high economic level, while $69.11 \%$ of mothers and $75.85 \%$ of fathers had normal high. See detail in Table 1.

In details, the prevalences of stunting among urban Indonesian children are also presented (Fig 2).

The statistical test showed that age and small size of birth (low birth weight, short newborn length) had associated with stunting children $(p<0.05)$, as detail in Table 2.

Results showed that parent's education, mother occupation, number of children $<5$ years, parent's high and economic status had an association with stunting. As detail in Table 3.

The best fit model of the multivariate test showed that risk factors for stunting children in

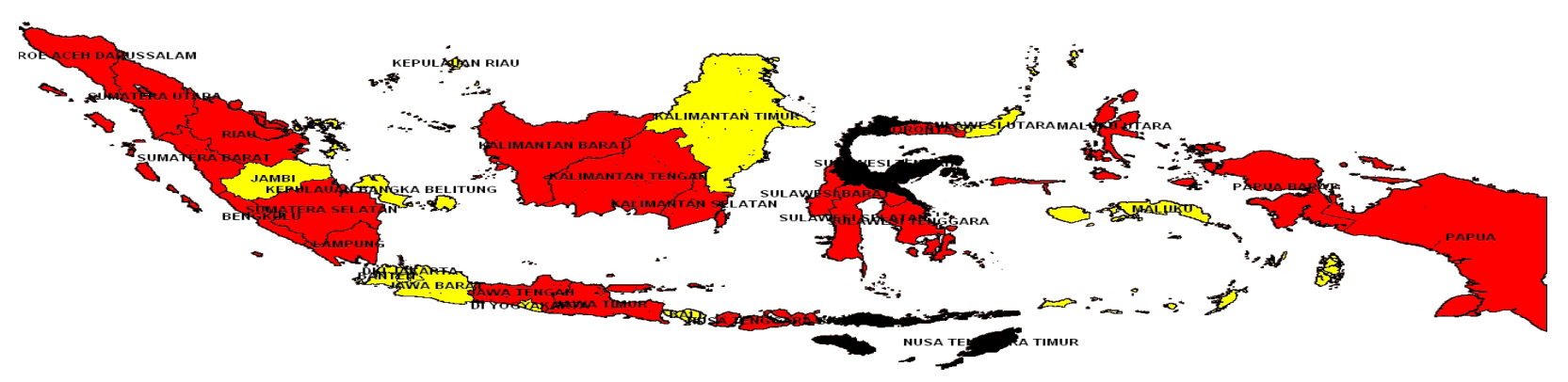

BALTA STUNTING (BALTAS)
\begin{tabular}{|l}
\hline \\
$\begin{array}{l}00-39 \\
40\end{array}$ \\
40 and More \\
\hline
\end{tabular}

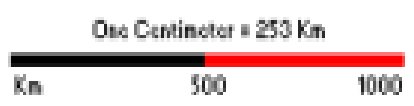

Fig 1. Prevalence stunting Indonesian children in the urban area Data source : Riskesdas, 2013 


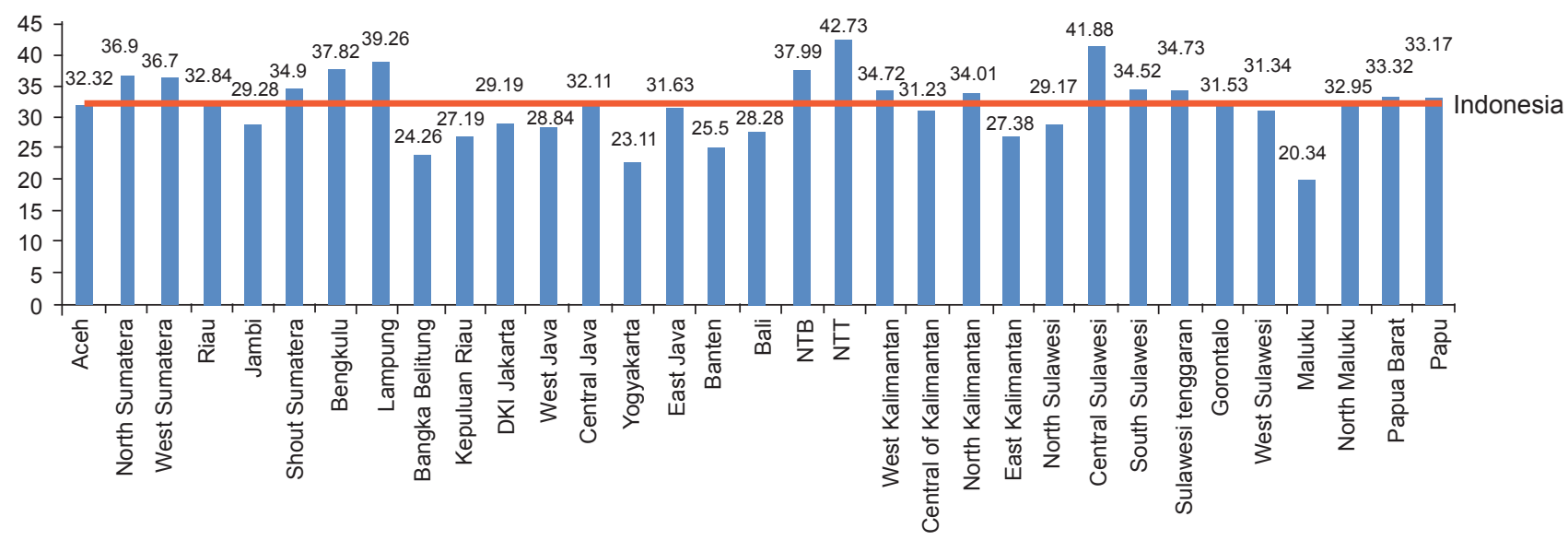

Fig 2. The prevalences of children stunting in urban Indonesia

Table 1. Household characteristics

\begin{tabular}{|c|c|c|}
\hline Variable & $\mathbf{n}$ & $\%$ \\
\hline \multicolumn{3}{|l|}{ Mother's education } \\
\hline Low & 2,390 & 18.04 \\
\hline Middle & 5,555 & 41.93 \\
\hline High & 5,303 & 40.03 \\
\hline \multicolumn{3}{|l|}{ Father's education } \\
\hline Low & 2,272 & 17.15 \\
\hline Middle & 6,030 & 45.52 \\
\hline High & 4,946 & 37.33 \\
\hline \multicolumn{3}{|l|}{ No of family member } \\
\hline$>4$ & 7,075 & 53.40 \\
\hline$\leq 4$ & 6,173 & 46.60 \\
\hline \multicolumn{3}{|l|}{ No of children $<5 y$} \\
\hline$\leq 2$ & 13,030 & 98.35 \\
\hline$>2$ & 218 & 1.65 \\
\hline \multicolumn{3}{|l|}{ Mother's occupation } \\
\hline Unemployed & 8,542 & 64.48 \\
\hline Employed & 4,706 & 35.52 \\
\hline \multicolumn{3}{|l|}{ Father's occupation } \\
\hline Unemployed & 438 & 3.31 \\
\hline Employed & 12,810 & 96.69 \\
\hline \multicolumn{3}{|l|}{ Economic status } \\
\hline Low & 1,551 & 11.71 \\
\hline Middle & 2,521 & 19.03 \\
\hline High & 9,176 & 69.26 \\
\hline \multicolumn{3}{|l|}{ Mother's high } \\
\hline Short & 4,092 & 0.893 \\
\hline Normal & 9,156 & 69.11 \\
\hline \multicolumn{3}{|l|}{ Father's high } \\
\hline Short & 3,199 & 24.15 \\
\hline Normal & 10,049 & 75.85 \\
\hline
\end{tabular}

Indonesian urban areas were size of birth (newborn length and birth weight), parental education, parental high, and economic status. As detail in Table 4.

This was a big data research in 33 province in Indonesia, representatives for all province in Indonesia children. But the limitation were the research was cross sectional design which have not explanation about natural histories of stunting children, and some direct variables such as food consumption was not observed.

\section{DISCUSSION}

This research showed that household economic and parental education level were significant determinants of stunting. According to WHO 2005, Social Determinants of Health (SDH) including economic, education and other structural factor interact affecting people health status (13). Education investment is a fundamental factor to achieve good health status (13) and eradicate stunting (19-21). Parent's education will affect knowledge of nutrition, good parenting and feeding practice, stimulate optimal growth children (2022), get opportunities for a better occupation, high economic and well-being, adequate social and network supports, and encouraging their children to get high educational level, healthy and good human resources (20, 22-24). In North-Eastern Iran, 2009 children were born from a low-educated parent were 
Table 2. Association of children and household characteristic with stunting

\begin{tabular}{|c|c|c|c|c|c|c|}
\hline \multirow{2}{*}{ Variable } & \multicolumn{2}{|c|}{ Stunting } & \multicolumn{2}{|c|}{ Normal } & \multirow{2}{*}{$\mathbf{P}$} & \multirow{2}{*}{ OR (CI 95\%) } \\
\hline & $\mathrm{n}$ & $\%$ & $\mathbf{n}$ & $\%$ & & \\
\hline \multicolumn{7}{|l|}{ Age of children } \\
\hline$>24$ mo's & 2,405 & 33.78 & 4,714 & 66.22 & 0.0019 & $1.08(1.029-1.136)$ \\
\hline$\leq 24$ mo's & 1,915 & 31.25 & 4,214 & 68.75 & & 1 \\
\hline \multicolumn{7}{|l|}{ Sex } \\
\hline Boy & 2,246 & 33.14 & 4,531 & 66.86 & 0.1806 & $1.034(0.985-1.086)$ \\
\hline Girl & 2,074 & 32.05 & 4,397 & 67.95 & & 1 \\
\hline \multicolumn{7}{|l|}{ Birth weight } \\
\hline Low & 280 & 43.61 & 362 & 56.39 & 0.000 & $1.36(1.242-1.490)$ \\
\hline Normal & 4,040 & 32.05 & 8,566 & 67.95 & & 1 \\
\hline \multicolumn{7}{|l|}{ Newborn length } \\
\hline Short & 918 & 99.84 & 1,448 & 15.76 & 0.000 & $1.24(1.171-1.315)$ \\
\hline Normal & 3,402 & 31.26 & 7,480 & 68.74 & & 1 \\
\hline
\end{tabular}

Table 3. Association between sociodemographic with stunting children

\begin{tabular}{|c|c|c|c|c|c|c|}
\hline \multirow{2}{*}{ Variable } & \multicolumn{2}{|c|}{ Stunting } & \multicolumn{2}{|c|}{ Normal } & \multirow{2}{*}{$\mathbf{P}$} & \multirow{2}{*}{ OR (CI95\%) } \\
\hline & $\mathbf{n}$ & $\%$ & n & $\%$ & & \\
\hline \multicolumn{7}{|l|}{ Mother's education } \\
\hline Low & 1,992 & 37.56 & 3,311 & 62.44 & 0.000 & $1.42(1.315-1.529)$ \\
\hline Middle & 1,695 & 30.51 & 3,860 & 69.49 & 0.000 & $1.15(1.066-1.245)$ \\
\hline High & 633 & 26.49 & 1,757 & 73.51 & & 1 \\
\hline \multicolumn{7}{|l|}{ Father's education } \\
\hline Low & 1,868 & 37.77 & 3,078 & 62.23 & 0.000 & $1.418(1.313-1.531)$ \\
\hline Middle & 1,847 & 30.63 & 4,183 & 69.37 & 0.000 & $1.150(1.064-1.243)$ \\
\hline High & 605 & 26.63 & 1,667 & 73.37 & & 1 \\
\hline \multicolumn{7}{|c|}{ Mother's occupation } \\
\hline Unemployed & 2,847 & 33.33 & 5,695 & 66.37 & 0.0171 & $1.065(1.001-1.122)$ \\
\hline Employed & 1,473 & 31.30 & 3,233 & 68.70 & & 1 \\
\hline \multicolumn{7}{|l|}{ Father's occupation } \\
\hline Unemployed & 129 & 29.45 & 309 & 70.55 & 0.1518 & $0.900(0.777-1.043)$ \\
\hline Employed & 4,191 & 32.72 & 8,619 & 67.28 & & 1 \\
\hline \multicolumn{7}{|c|}{ No of household member } \\
\hline$>4$ & 2,047 & 33.16 & 4,126 & 66.84 & 0.206 & $1.032(0.983-1.084)$ \\
\hline$\leq 4$ & 2,273 & 32.13 & 4,802 & 67.87 & & 1 \\
\hline \multicolumn{7}{|l|}{ No of children $<5 y$} \\
\hline$>2$ & 86 & 37.45 & 132 & 60.55 & 0.0298 & $1.214(1.028-1.434)$ \\
\hline$\leq 2$ & 4,234 & 32.49 & 8,796 & 67.51 & & 1 \\
\hline \multicolumn{7}{|l|}{ Mother's high } \\
\hline Short & 1,606 & 39.25 & 2,486 & 60.75 & 0.000 & $1.32(1.260-1.391)$ \\
\hline Normal & 2,714 & 29.65 & 6,442 & 70.35 & & 1 \\
\hline \multicolumn{7}{|l|}{ Father's high } \\
\hline Short & 1,291 & 29.88 & 3,029 & 70.12 & 0.000 & $1.398(1.316-1.486)$ \\
\hline Normal & 1,908 & 21.37 & 7,020 & 78.63 & & 1 \\
\hline \multicolumn{7}{|l|}{ Economic status } \\
\hline Low & 667 & 43.00 & 884 & 57.00 & 0.000 & $1.452(1.359-1.549)$ \\
\hline Middle & 935 & 37.09 & 1,586 & 62.91 & 0.000 & $1.252(1.179-1.329)$ \\
\hline High & 2,718 & 29.62 & 6,458 & 70.38 & & 1 \\
\hline
\end{tabular}


Table 4. Adjusted odds ratio determinant factors for stunting children

\begin{tabular}{|c|c|c|}
\hline Variable & $\mathbf{P}$ & AOR $(95 \%)$ \\
\hline \multicolumn{3}{|l|}{ Newborn length } \\
\hline Short & 0.000 & $1.16(1.09-1.23)^{\star * *}$ \\
\hline Normal & & 1 \\
\hline \multicolumn{3}{|l|}{ Birth weight } \\
\hline Low & 0.000 & $1.2(1.09-1.32)^{\star \star *}$ \\
\hline Normal & & 1 \\
\hline \multicolumn{3}{|c|}{ Mother's education } \\
\hline Low & 0.014 & $1.14(1.03-1.26)^{*}$ \\
\hline Middle & 0.203 & $1.06(0.97-1.16)$ \\
\hline High & & 1 \\
\hline \multicolumn{3}{|c|}{ Father's education } \\
\hline Low & 0.020 & $1.13(1.02-1.23)^{*}$ \\
\hline Middle & 0.226 & $1.06(0.97-1.16)$ \\
\hline High & & 1 \\
\hline \multicolumn{3}{|l|}{ Mother's height } \\
\hline Short & 0.000 & $1.23(1.17-1.29)^{* * *}$ \\
\hline Normal & & 1 \\
\hline \multicolumn{3}{|l|}{ Father's height } \\
\hline Short & 0.000 & $1.24(1.18-1.31)^{* * *}$ \\
\hline Normal & & 1 \\
\hline \multicolumn{3}{|c|}{ Household economic status } \\
\hline Low & 0.000 & $1.24(1.15-1.33)^{\star * *}$ \\
\hline Middle & 0.000 & $1.12(1.06-1.20)^{\star \star \star}$ \\
\hline High & & 1 \\
\hline
\end{tabular}

Note : ${ }^{*} p<0.05,{ }^{* * *} p<0.001$

$15 \%$ more likely to be stunting than well-educated ones (22).

Another social factor affecting stunting children was of economic status. Economic is the root of the malnutrition problem. Poor people had limited ability to buy and select good quality food, health and recreation facilities and infrastructure, good water access and housing so that the children were at a greater risk of malnutrition (23-24). Research showed that low economic status more likely to have stunted children than the higher level of economic (OR 1.24, 95\%Cl: 1.15-1.33) (see Table 4).

This research showed that short parent more likely to have stunting children than normal. However, the genetic was not prior, it just contributed to a $15 \%$ risk factors (25). The major risk factors were environment, such as nutrition, pollution, clean water, hygiene-sanitation, housing, infection affect the fetus health status $(23,26)$. Short mother also reflected chronic malnutrition since the prenatal period, so that mother have small pelvic, and fetus tend to suffer from nutrition and oxygen supply deficiency (25. Maternal need support to got a healthy pregnancy outcome, both sensitive and specific intervention (27).

This research showed that low birth weight and short newborn's length were strong determinants of stunted children. Based on many studies, low birth weight was the most dominant factor for early stunting children (24,28-29). Small birth (low birth weight and short length newborn) is due to chronic malnutrition even before pregnancy period (30-31). As because stunting is a chronic condition that illustrates stunted growth due to long-term malnutrition and manifestations of low birth weight (LBW) and malnutrition in infancy and the absence of perfect catch-up growth in subsequent periods he long deficit of low birth weight and short newborn.

Stunted children who achieved catch-up growth during the golden period-in the first 1000 days of life would grow with normal height in adolescents and adults. They need support by adequate nutrition in quantity and quality including breastfeeding and supplementary feeding (32), smoke-free pollution (33), clean water access, healthy housing, good hygiene and sanitation for optimum growth (15), intervention and prevention recurrent infection (15), supplementation of micronutrients (26), improvement in household economics (34-35). Cohort study with IFLS shows that stunted children who recatch-up in an early age as many as $84 \%$ grew as a normal height toddler, while they who failed recatch-up in critical period (early 1000 day of life) $77 \%$ would remain stunting during the pre-puberty period (35). However, stunting in early life tend to grow stunting in toddlers, children, teenagers and adults with many consequences in later life (4), The improvement of maternal and children nutritional status as long as the window of opportunity period will prevent chronic children malnutrition including LBW and stunting (23), and increasing macro and micro economic (36). In Indonesia, investment in maternal health and children give benefit 48 time (36). 


\section{CONCLUSION}

As many as $32.16 \%$ of Indonesian children in urban areas was stunting. Factors significantly related to stunting are size of birth (small birth weight and short length), short-stature parents, and social factors such as low parental educational level, house hold economic. Based on this research, intervention on prenatal care and maternal health care should be focused on decreasing the rate of small birth-size, and implementing the 1000 first day of life programs such as parental nutrition education in order to increase knowledge, attitude, and practices related to child health and nutrition.

\section{ACKNOWLEDGEMENT}

We gratefully acknowledge to Natonal Instistute Health Research and Development (NIHRD) for the subset data, and Board for Development and Empowerment Human Resources of Health (BPPSDMK) for funding.

\section{REFERENCES}

1. WHO. Joint child malnutrition estimates - Levels and trends (2017 edition). In 2017.

2. Coulter JBS. Nutrition and malnutrition in lowand middle-income countries. Paediatr Int Child Health. 2014;34(4):233-5.

3. Hoddinott J, Behrman JR, Maluccio JA, Melgar $P$, Quisumbing AR, Ramirez-Zea M, et al. Adult consequences of growth failure in early childhood. Am J Clin Nutr. 2013;98(5):1170-8.

4. Dewey KG, Begum K. Long-term consequences of stunting in early life. Matern Child Nutr. 2011 Oct Suppl 3:5-18.

5. Kimani-Murage E, Kahn K. The prevalence of stunting, overweight and obesity, and metabolic disease risk in rural South African children. BMC public. 2010;1-13.

6. Rolfe, E. D. L., Vinı, G., Vianna, A., Gigante, D. P., Miranda, J. J., Yudkin, J. S., Horta, L. and Ong, K. K. Associations of stunting in early childhood with cardiometabolic risk factors in adulthood', 2018. pp. 1-13. doi: 10.1371/journal. pone.0192196.
7. Grillo LP, Gigante DP, Horta BL, de Barros FCF. Childhood stunting and the metabolic syndrome components in young adults from a Brazilian birth cohort study. Eur J Clin Nutr. Nature Publishing Group; 2016;70(5):548-53.

8. Febba A, Sesso R, Barreto GP, Liboni CS, Franco MCP, Casarini DE. Stunting growth : association of the blood pressure levels and ACE activity in early childhood. 2009;379-86.

9. WHO. Sustainable Development Goals [Internet]. 2015. Available from: http://www. un.org/sustainabledevelopment/sustainabledevelopment-goals/

10. Badan Penelitian dan Pengembangan Kesehatan RI. Riset Kesehatan Dasar (RISKESDAS) Tahun 2010. 2010;1-111.

11. Badan Penelitian dan Pengembangan Kesehatan RI. Riset Kesehatan Dasar (RISKESDAS) 2013. 2013;1-384.

12. WHO. The double burden of malnutrition Policy Brief. 2015. Available from : https:WHO-NMHNHD-17.3-eng.pdf?ua=1, retrieved $1^{\text {st }}$ July 2019.

13. Braveman $P$. The Social Determinants of Health : It 's Time to Consider the Causes of the Causes. 129:19-31.

14. Unicef Office of Research. Structural Determinants of Child Well-being. 2012.

15. Torlesse H, Cronin AA, Sebayang SK, Nandy R. Determinants of stunting in Indonesian children: evidence from a cross-sectional survey indicate a prominent role for the water, sanitation and hygiene sector in stunting reduction. BMC Public Health. 2016;16(1).

16. Srinivasan CS, Zanello G, Shankar B, Poel E Van de, O O, Smith L, et al. Rural-urban disparities in child nutrition in Bangladesh and Nepal. BMC Public Health.2013 (1):581.

17. Mbuya MNN, Chidem M, Chasekwa B, Mishra V. Biological, Social, and Environmental Determinants of Low Birth Weight and Stunting among Infants and Young Children in Zimbabwe. Zimbabwe Work Pap. 2010;(7).

18. Kien VD, Lee H, Nam Y, Oh J. Trends in socioeconomic inequalities in child malnutrition in Vietnam: findings from the Multiple Indicator Cluster Surveys, 2000- 2011. 2016;1:1-9. 
19. Braveman P, Egerter S, Barclay C. Income , Wealth and Health. Explor Soc Determ Heal. 2011;(April).

20. Egerter S, Braveman P, Sadegh-Nobari T, Grossman-Khan R, Dekker M. Education Matters for Health. 2009;(September):1-15.

21. Khongsdier R. Malnutrition, Social Inequality and Natural Selection in Human Populations. Hum Ecol. 2006;Ecology, C(14):49-63.

22. Emamian MH, Fateh M, Gorgani N, Fotouhi A. Mother's education is the most important factor in socio-economic inequality of child stunting in Iran. Public Health Nutr. 2013;17(5):1-6.

23. Akombi BJ, Agho KE, Hall JJ, Merom D, AstellBurt T, Renzaho AMN. Stunting and severe stunting among children under-5 years in Nigeria: A multilevel analysis. BMC Pediatr. 2017;17(1):15.

24. Ikeda N, Irie Y, Shibuya K. Determinants of reduced child stunting in Cambodia: analysis of pooled data from three demographic and health surveys. Bull World Health Organ. 2013;91(February):341-9.

25. Duggal P. Does Malnutrition Have a Genetic Component ?. Annu Rev gennon Hum Genet. 2018;(May):1-16

26. Blaney S, Februhartanty J, Sukotjo S. Feeding practices among Indonesian children above six months of age: A literature review on their magnitude and quality (part 1). Asia Pac J Clin Nutr. 2015;24(1):16-27.

27. Rosha, B.C., Sari, K., Yunita I., Amaliah. N., Utami, N.H. Peran Intervensi Gizi Spesifik dan Sensitif dalam Perbaikan Masalah Gizi Balita di Kota Bogor, Buletin Penelitian Kesehatan. 2016: 44 (2). 127 - 138
28. Aryastami NK, Pusat J, Secondary CA, Author C, Aryastami NK, Shankar A, et al. BMC Nutrition Low Birth Weight was the most dominant predictor associated with stunting among children aged 12-23 months in Indonesia. BMC Nutrition; 2017;1-6.

29. Anjum F, Javed T, Afzal MF, Sheikh GA. Maternal Risk Factors Associated with Low Birth Weight : A Case Control Study. 2011;17(3):223-8.

30. Khanal V, Sauer K, Karkee R, Zhao Y. Factors associated with small size at birth in Nepal: further analysis of Nepal Demographic and Health Survey 2011. BMC Pregnancy Childbirth. 2014;14(1):32.

31. Krebs NF, Mazariegos M, Chomba E, Sami N, Pasha O, Tshefu A, et al. Randomized controlled trial of meat compared with multimicronutrientfortified cereal in infants and toddlers with high stunting rates in diverse settings $1-3$. 2012;840-7.

32. Kyu HH, Georgiades K, Boyle M. Maternal smoking, biofuel smoke exposure and child height-for-age in seven developing countries. Int J Epidemiol. 2009;38(5):1342-50.

33. Taulbut M, Walsh D. Poverty, Parenting and Poor Health: Comparing Early Years' Experiences in Scotland, England and Three City Regions. Glas Cent Popul Heal. 2013;(December):1-139.

34. Babar NF, Muzaffar R, Khan M, Imdad S. Impact of Socioeconomic Factors on Nutritional Status in Primary School Children. J Ayub Med Coll Abbottabad. 2010;22(4):15-8.

35. Hoddinott J, Alderman H, Behrman JR, Haddad $L$, Horton S. The economic rationale for investing in stunting reduction. Matern Child Nutr. 2013;2020(S2):69-82. 